\title{
Prawnoekonomiczne aspekty funkcjonowania VAT w rolnictwie
}

\author{
Legal and economic aspects of VAT in agriculture
}

\section{Wprowadzenie}

Podatek VAT (ang. Value Added Tax - VAT) w Polskim ustawodawstwie funkcjonujący jako podatek od towarów i usług (PTU) obciąża tzw. wartość dodaną na każdym etapie produkcji i dystrybucji poszczególnych dóbr. Wprowadzono go na podstawie ustawy z dnia 8 stycznia $1993 \mathrm{r}$. o podatku od towarów i usług oraz o podatku akcyzowym (Dz.U. 1993, nr 11, poz. 50; dalej: ustawa o VAT)1. Wiązało się to z powstaniem nie tylko wielu problemów organizacyjnych, lecz także finansowych i mentalnych ${ }^{2}$. To z kolei oznaczało konieczność pokonania wielu barier we właściwym jego zrozumieniu i ujmowaniu oraz ocenie prawnoekonomicznych skutków, jakie mógł powodować. Podatek VAT oparty jest na wartości dodanej i wynika z założeń Pierwszej dyrektywy Rady Unii Europejskiej z 11 kwietnia 1967 r. (dalej: Pierwsza dyrektywa) oraz z orzecznictwa Europejskiego Trybunału Sprawiedliwości (Tokarski i in., 2015, s. 211). Perspektywa

\footnotetext{
${ }^{1}$ W Polsce pierwszy projekt ustawy dotyczący VAT został wniesiony do Sejmu w 1990 r. Termin wejścia w życie ustawy określono początkowo na 1 stycznia $1991 \mathrm{r}$. Z różnych względów był on jednak przesuwany, by definitywnie zostać wprowadzony 5 lipca $1993 \mathrm{r}$.

${ }^{2}$ Za Namysłowski, Pokrop (2012, s. 17-18) można stwierdzić, że: „Obrazowo rzecz ujmując: świat-VAT to zapętlony, wielowarstwowy konglomerat, który jest «podatkowym lunaparkiem, gdzie rzeczywistość i zasady prawa są zawieszone lub odwrócone» (tak Lord Justice Sedley w orzeczeniu w sprawie Royal \& Sun Alliance UK), a przepisy to "gąszcz splątany niczym spaghetti» (za prof. Benem J.M. Terra). W ten «Matrix» wrzućmy jeszcze polskie ingrediencje, którym nieobce są zawiłość, niespójność i specyficzna sofistyka, a otrzymamy mieszankę, którą niełatwo strawić".
} 
przystąpienia Polski do $\mathrm{UE}^{3}$ wymusiła proces zbliżania przepisów prawnych, w tym m.in. dotyczących pośredniego systemu opodatkowania. Ustawa o VAT z 1993 r. poprzez zastąpienie wcześniej obowiązującego podatku obrotowego podatkiem od towarów i usług wypełniła postulat zawarty w art. 1 obowiązującej w tym okresie Pierwszej dyrektywy ${ }^{4}$. Nie zapewniała jednak pełnej realizacji podstawowych zasad funkcjonowania podatku od wartości dodanej, tj. neutralności podatku oraz powszechności opodatkowania. Przed przystąpieniem Polski do Wspólnoty prawo do odliczania traktowane było częstokroć jako szczególny przywilej, nie prawo samoistne, lecz warunkowe. Interpretacja zasad podatku od wartości dodanej w taki sposób naruszała zasadę neutralności i powszechności podatku VAT dla podatników, wyrażoną w art. 2 Pierwszej dyrektywy VAT UE (obecnie art. 1 Pierwszej dyrektywy).

Dodatkowo dochodziły problemy właściwej interpretacji samych przepisów i skutków, jakie one wywołują. Nie ominęły one działalności rolniczej. Okazało się bowiem, że wprowadzenie VAT i jego funkcjonowanie w rolnictwie jest bardzo różnie interpretowane. Dotyczy to przede wszystkim konsekwencji w zakresie płynności i rentowności dla gospodarstw rolników ryczałtowych oraz rozliczających się na zasadach ogólnych. Według Kondraszuka (2016, s. 155) „Problemy z właściwym rozumieniem funkcjonowania VAT w rolnictwie mają długą historię”. Już na samym początku podatek ten kojarzył się z dodatkowymi obciążeniami. Właśnie niezrozumienie jego istoty spowodowało, że chcąc w 1993 r. wybrać jak najlepiej, zdecydowano o zwolnieniu VAT i rolnicy przy zakupach środków produkcji traktowani byli jak ostateczni odbiorcy (konsumenci). Sprzedaż płodów rolnych została zwolniona z VAT. Rozwiązanie takie, choć nie nakładało na rolników żadnych obowiązków wynikających z przepisów dotyczących podatku od towarów i usług, to pod względem ekonomicznym i finansowym było dla nich niekorzystne, ponieważ obciążał ich VAT, który musieli płacić w cenach towarów i usług nabywanych w celu prowadzenia produkcji rolnej. Potrzebna była zmiana. Jednak dopiero pod koniec 1999 r. zintensyfikowano prace nad projektem zmian w podatku od towarów i usług w obszarze rolnictwa (Kondraszuk 2016, s. 156). Początkowo rząd chciał, aby rolnicy indywidualni otrzymywali ryczałtowy zwrot VAT. Posłowie uznali jednak, że trzeba zostawić rolnikom możliwość wyboru.

\footnotetext{
${ }^{3}$ Układ europejski ustanawiający stowarzyszenie między Rzeczpospolitą Polską, z jednej strony, a Wspólnotami Europejskimi i ich Państwami Członkowskimi, z drugiej strony, sporządzony w Brukseli dnia 16 grudnia 1991 r. (Dz.U.1994, nr 11, poz. 38).

${ }^{4}$ Zgodnie z art. 1 Pierwszej dyrektywy państwa członkowskie zostały zobowiązane do zastąpienia funkcjonującego w ich krajach systemu podatków obrotowych wspólnym systemem podatku od wartości dodanej zdefiniowanym w art. 2 Pierwszej dyrektywy.
} 
Albo będą rozliczać zryczałtowany podatek od towarów i usług, albo na tzw. zasadach ogólnych, czyli tak jak normalne firmy. Trwały również ożywione dyskusje nad wprowadzeniem stawki zerowej VAT w rolnictwie ${ }^{5}$. W rezultacie długich debat nad zmianą ustawy o podatku od towarów i usług 20 lipca $2000 \mathrm{r}$. Sejm przyjmując poprawkę Senatu do zmian wyżej wymienionej ustawy, zadecydował o wprowadzeniu 3\% stawki VAT w rolnictwie z dniem 4 września $2000 \mathrm{r}^{6}{ }^{6}$

W międzyczasie przez lata 1993-2000 funkcjonowało niekorzystne dla rolników rozwiązanie dotyczące podatku VAT. Generalnie rolnicy byli pozbawieni możliwości rozliczania tego podatku i korzystania z dobrodziejstwa zasady jego neutralności.

Przystąpienie Polski do UE i wejście 1 maja 2004 r. w życie nowej, sharmonizowanej ustawy o VAT spowodowało duże zmiany w postrzeganiu i stosowaniu przepisów dotyczących VAT. Zmieniły się zasady wykładni przepisów dotyczących tego podatku. Te obecnie obowiązujące w zdecydowanie większym stopniu realizują zasadę neutralności i powszechności opodatkowania.

Jednak - jak wykazał Kondraszuk (2016, s. 159) - „pomimo kilkunastoletniego obowiązywania podatku VAT w rolnictwie jego zasady funkcjonowania są niewłaściwie interpretowane i błędnie prezentowane jego skutki”.

Tematyka podatku od towarów i usług podejmowana była również przez innych autorów. W zasadzie już wszystko zostało wyjaśnione i nie powinno być żadnych wątpliwości co do zasad jego funkcjonowania i skutków, jakie wywołuje dla sytuacji ekonomiczno-finansowej prowadzonej działalności. W stosunku do rolnictwa temat ten podejmowali m.in. Szelągowska, Goraj (2000), Dziemianowicz (2006), Węgrzyn (2007), Filipiak (2007), Gruziel (2009), Turowska (2010), Zabielska (2011), Brodzińska (2015), Nachtman i Cholewa (2016).

Próbę dalszego poszukiwania właściwego rozwiązania podjął autor (Kondraszuk 2017b, Kondraszuk, Jaworski 2017, 2018ab). Celem artykułu jest dokonanie reasumpcji dotychczasowych rozważań i pokazanie różnorodnych aspektów

${ }^{5}$ Projekt wprowadzenia zerowej stawki VAT $\mathrm{w}$ rolnictwie został przeforsowany podczas debaty sejmowej 12 maja 2000 r. Zdaniem rządu koszty stawki zerowej dla budżetu wynosiłyby ok. 1,3 mln zł. Gdyby Sejm zaakceptował rozważaną stawkę $0 \%$, wówczas rolnicy rozliczający się według zasad ogólnych nie płaciliby ani złotówki, za to mogliby w całości odliczać VAT płacony w zakupach (tak jest w Wielkiej Brytanii).

${ }^{6}$ Dla rolników było to korzystne rozwiązanie. Objęcie działalności rolniczej regulacją podatku od towarów i usług stworzyło możliwość odzyskania podatku VAT naliczonego w dokonanych przez nich zakupach, związanych z prowadzeniem gospodarstwa rolniczego. Jednocześnie rolnicy mieli prawo wyboru, przepisy ustawy o podatku od towarów i usług bowiem nakładały obowiązek stosowania zasad ogólnych rozliczania VAT w rolnictwie tylko w stosunku do podatników zobowiązanych do prowadzenia ksiąg rachunkowych. Pozostali rolnicy objęci zostali systemem ryczałtowym, ale mogli również przejść na zasady ogólne rozliczania VAT. 
prawnoekonomicznych związanych z ewidencją i rozliczaniem VAT w rolnictwie. Ukazano wady proponowanych rozwiązań i wskazano na liczne błędy w interpretacji funkcjonowania tego podatku w rolnictwie. W pierwszej kolejności omówiono błędy w wybranych opracowaniach i publikacjach (za okres 2010-2018) na temat VAT. Dodatkowo poddano weryfikacji proponowane algorytmy kalkulacji na stronach internetowych, dotyczące problemu: czy rolnikowi opłaca się być czynnym podatnikiem VAT? (http://ksiegowosc.infor.pl/) oraz VAT w rolnictwie: ryczałt czy VAT? (www.podatki.egospodarka.pl).

\section{Prawne podstawy rozliczania VAT w rolnictwie}

Problem ujmowania VAT na etapie ewidencji i sporządzania sprawozdań finansowych dotyczy wszystkich podmiotów gospodarczych w rolnictwie, dlatego w pierwszej kolejności przedstawiony zostanie system ewidencji i rozliczeń podatku VAT dla gospodarstw podlegających ustawie z dnia 29 września $1994 \mathrm{r}$. o rachunkowości (Dz.U. 1994, nr 121, poz. 591, dalej: UoR), a następnie w gospodarstwach niezobowiązanych do prowadzenia ksiąg rachunkowych, a tym samym niezobligowanych do rozliczania VAT na zasadach ogólnych.

\subsection{Gospodarstwa podlegające UoR}

Gospodarstwa takie (przedsiębiorstwa rolnicze) prowadzą księgi handlowe. Muszą one rozliczać się z podatku od towarów i usług na zasadach ogólnych. Rozwiązania, które stosują w tym zakresie, są identyczne ze przyjętymi w innych branżach i można uznać je za modelowe.

Stosując metodę fakturową/memoriałową, jako takie realizują podstawową zasadę neutralności podatku VAT i nie wywołują potrzeby analizy ich wpływu na wynik finansowy przedsiębiorstw. Prowadzenie pełnej rachunkowości umożliwia terminowe i prawidłowe sporządzanie potrzebnych zestawień dla rozliczeń VAT. Księgowi prowadzący księgi handlowe mogą bez większych problemów sporządzić potrzebne deklaracje dla jego rozliczeń. Podstawowymi dokumentami niezbędnymi do prowadzenia takiej ewidencji są faktury VAT, faktury korygujące oraz dokumenty celne. Na potrzeby rozliczania podatku od towarów i usług są one księgowane na kontach rozrachunkowych z urzędami skarbowymi. Generalnie jedną z podstawowych zasad VAT jest jego neutralność ekonomiczna. W praktyce oznacza to, że naliczony (zawarty w zakupach) nie jest kosztem, a należny (zawarty w sprzedaży) nie jest przychodem. 
Sprawa komplikuje się, kiedy z przepisów szczegółowych wynika, że nie cały VAT może podlegać odliczeniu. Wtedy staje się on kosztem i obciąża rachunek wyników, podobnie jak pozostałe koszty rodzajowe.

Ważną rolę odgrywają tzw. rejestry VAT. W programach komputerowych są one automatycznie powiązane $\mathrm{z}$ fakturami zakupu i sprzedaży oraz gwarantują prawidłowe rozliczenie podatku. Na podstawie rejestrów sporządzana jest deklaracja dla podatku dla VAT-7. Rozliczenie podatku od towarów i usług prowadzone jest na kontach rozrachunków (zespół 2), które nie mają „„tyczności” z kontami wynikowymi. Jest to gwarancja zachowania zasady neutralności, która oznacza, że podmiot gospodarczy nie ponosi ciężaru ekonomicznego tego podatku, gdyż na każdym etapie ewidencji podatnicy korzystają z prawa do odliczenia od podatku należnego (uzyskanego) podatku naliczonego (zapłaconego) przy nabyciu towarów i usług. Ewentualna nadwyżka jest przekazywana do urzędu skarbowego. W sytuacji, kiedy podatek zapłacony przewyższa uzyskany, podatnik ma prawo do obniżenia o tę różnicę kwotę podatku należnego za następne okresy lub do zwrotu różnicy z urzędu skarbowego. Ciężar VAT ponosi wyłącznie ostateczny konsument towaru lub usługi, będący końcowym ogniwem obrotu. Należy zauważyć, że w sytuacji, kiedy podatnik musi zapłacić należny podatek przed otrzymaniem od odbiorcy środków pieniężnych, może to istotnie pogorszyć jego sytuację finansową. Powstaną wtedy należności, od których zapłacony zostanie VAT. Podatnik może skorygować podatek należny w przypadku wierzytelności, których nieściągalność została uprawdopodobniona.

W tej sytuacji zastosowane zasady rozliczeń VAT w gospodarstwie (przedsiębiorstwie) rolniczym nie różnią się od rozwiązań ewidencyjnych stosowanych w innych przedsiębiorstwach. Jedynie w rejestrach VAT widoczna jest specyfika produkcji rolniczej, bo wyszczególniony jest podatek VAT w wysokości 5\% i 8\% na towary i usługi związane $\mathrm{z}$ rolnictwem.

Po zakończeniu miesiąca kwota podatku VAT naliczonego jest rozliczana, tj. podlega odliczeniu od podatku VAT należnego. W sytuacji, gdy w danym miesiącu wystąpił zakup z podatkiem VAT niepodlegającym odliczeniu, to nie będzie on wykazany jako naliczony, wcześniej bowiem został przeksięgowany na konto „podatki i opłaty”. Konto „VAT naliczony i jego rozliczenie” może wykazywać wyłącznie saldo debetowe, oznaczające podatek VAT naliczony, w stosunku do którego jednostce przysługuje prawo do obniżenia kwoty podatku należnego, lecz w rozliczeniu za okres następny. Na koncie syntetycznym „VAT należny i jego rozliczenie" ewidencjonuje się podatek VAT należny od sprzedaży własnej, czynności związanych ze sprzedażą oraz od importu usług. Każda operacja zaksięgowana na tym koncie musi być udokumentowana wystawionymi 
fakturami VAT lub fakturami korygującymi VAT przekazanymi kontrahentom. Ewidencja analityczna umożliwia prawidłowe sporządzenie deklaracji VAT-7. Dokonując zapisu na koncie „VAT należny i jego rozliczenie”, zapisana kwota jest jednocześnie przenoszona do rejestru sprzedaży i ujmowana w deklaracji VAT-7 za dany miesiąc. Jeżeli podmiot dokonuje sprzedaży zwolnionej z podatku VAT - sprzedając np. maszyny rolnicze, dla których w momencie zakupu nie przysługiwało prawo do odliczenia podatku VAT, to wykazuje sprzedaż w ewidencji księgowej i jednocześnie w ewidencji sprzedaży VAT z zapisem w rejestrze VAT wartości zerowej podatku. Konto „VAT należny i jego rozliczenie” na koniec miesiąca nie wykazuje salda, ponieważ kwotę podatku należnego za dany miesiąc przeksięgowuje się na konto „Rozrachunki z urzędem skarbowym z tytułu podatku VAT”, służące końcowemu rozliczeniu z tytułu podatku VAT za dany miesiąc. Jeżeli kwota podatku naliczonego w okresie rozliczeniowym jest wyższa od kwoty podatku należnego, podatnikowi zgodnie z art. 86 ust. 1 ustawy o VAT przysługuje prawo do obniżenia podatku należnego w następnych okresach lub zwrot różnicy na rachunek bankowy.

W tym przypadku funkcjonuje jeden obieg dokumentów w ramach ewidencji metodą memoriałową (możemy mówić o zintegrowanym systemie księgowym i rozliczania podatku VAT - dane automatycznie przenoszone są do właściwych rejestrów VAT). Próbę integracji ewidencji metodą kasową z rozliczaniem VAT podjął autor w opracowaniach (Kondraszuk 2017b, 2018).

\subsection{Gospodarstwa niepodlegające UoR}

Pozostałe gospodarstwa objęte są systemem ryczałtowym z możliwością (wg własnego uznania) rozliczania VAT na zasadach ogólnych. Ustawa wprowadza szczególny sposób rozliczania tego podatku przez rolnika ryczałtowego. Istota uproszczonego opodatkowania rolników sprowadza się do zwolnienia ich z uciążliwych obciążeń administracyjnych i stworzenia możliwie prostego systemu zwrotu podatku. To nie rolnik, a odbiorca jego produktów rolnych, będący podatnikiem VAT, nalicza do ceny netto obecnie 7\% VAT, mający zrekompensować rolnikowi podatek zawarty w dokonanych przez niego zakupach, a następnie całą należność przekazuje na konto rolnika. Zapłata należności za produkty rolne na rachunek bankowy umożliwiała kupującemu zwiększenie swojego podatku naliczonego podlegającego odliczeniu w rozliczeniu VAT z urzędem skarbowym. Nie może jednak dokonywać rozliczeń gotówkowych z rolnikami, a tylko prze- 
syłać pieniądze na ich rachunek (np. ROR). Rozwiązanie to wprowadzono, aby zapobiec ewentualnym nadużyciom podatkowym ${ }^{7}$.

Po przejściu na zasady ogólne podatnicy VAT mają obowiązek prowadzenia właściwej ewidencji zakupów towarów i usług nabywanych do produkcji rolnej oraz sprzedaży nieprzetworzonych produktów rolnych. Obecnie jedynym warunkiem rezygnacji ze zwolnienia jest złożenie zgłoszenia rejestracyjnego dla celów podatku VAT (nowelizacja ustawy o VAT z dnia 1 grudnia 2008 r., Dz.U. 2008, $\mathrm{nr} 209$, poz. 1320). Wcześniej rolnik mógł zrezygnować ze statusu rolnika ryczałtowego, jeżeli w poprzednim roku podatkowym dokonał dostawy produktów rolnych i usług rolniczych o wartości przekraczającej 20000 zł. Przepis ten był sprzeczny z postanowieniami rozdziału 2 XII Dyrektywy VAT, zgodnie z którym każdy rolnik powinien mieć prawo do przejścia na zasady ogólne opodatkowania. Ewentualne limity mogą być nakładane w stosunku do obrotów jedynie jako narzędzie służące zapewnieniu, że systemowi ryczałtowemu podlegają wyłącznie małe gospodarstwa. Ponadto za naruszające przepisy dyrektywy VAT należało uznać warunki rezygnacji ze zryczałtowanego systemu opodatkowania rolników, które uniemożliwiały podmiotowi rozpoczynającemu działalność od samego początku przejście na zasady ogólne. Mógł to zrobić dopiero po upływie 3 miesięcy (przez taki okres podmiot zamierzający zrezygnować z ryczałtowego opodatkowania musiał prowadzić ewidencję podatkową).

\section{Ekonomiczne i finansowe skutki pozostawania przez rolników na ryczałcie}

Możliwość rozliczania VAT, w formie zryczałtowanej i według zasad ogólnych, ułatwia rolnikowi podjęcie decyzji o wyborze korzystniejszego rozwiązania (optymalizacji podatkowej). Kryterium wyboru powinno uwzględniać zarówno aspekty ekonomiczne, jak i finansowe, a także preferencje organizacyjne oraz mentalne. Wielką zaletą pozostawania na ryczałcie jest to, że w zakresie prowadzonej działalności rolniczej rolnik został praktycznie zwolniony ze wszystkich obowiązków, jakim podlega w ramach VAT rozliczający się na zasadach ogólnych. Jest to zgodne z obowiązującą w Unii dyrektywą Rady 2006/112/WE z dnia 28 listopada 2006 r. w sprawie wspólnego systemu podatku od wartości dodanej. Obejmuje ona również działalność rolniczą. Punkt 50 w postanowieniach do dyrektywy stanowi, że

\footnotetext{
${ }^{7}$ Rolnik po rezygnacji z ryczałtu i przejściu na zasady ogólne może ponownie powrócić do ryczałtu, ale dopiero po upływie 3 lat od daty przejścia na zasady ogólne.
} 
W odniesieniu do rolników państwa członkowskie powinny zachować swobodę stosowania procedury szczególnej obejmującej zastosowanie zryczałtowanych rekompensat VAT naliczonego na rzecz rolników nieobjętych zasadami ogólnymi. Należy ustanowić podstawowe zasady tej procedury szczególnej oraz przyjąć wspólną metodę określania wartości dodanej zrealizowanej przez takich rolników, do celów poboru zasobów własnych.

Kupujący produkty rolne nalicza do wartości netto zakupionego towaru podatek, który będzie traktowany jako podatek naliczony i zwrócony (rozliczony) przez urząd skarbowy. Rolnik ryczałtowy może traktować tę kwotę jako rodzaj przychodu (zryczałtowany zwrot). Jednak są i minusy takiego rozwiązania, ponosi on bowiem pełne obciążenie podatkiem VAT w zakupionych środkach produkcji (obrotowych i trwałych). Będzie to dla rolnika rodzaj kosztu, który należy odliczyć od uzyskanego zwrotu zryczałtowanego uzyskanego przy sprzedaży. W tej sytuacji nie ma mowy o neutralności ekonomicznej i finansowej. W ten sposób odchodzi się od jednej z najważniejszych zasad podatku VAT, a mianowicie zasady neutralności. Powstaje dodatkowy dochód lub strata u rolnika ryczałtowego z tytułu wybrania tej formy rozliczania VAT.

Rolnicy, którzy zrezygnowali z ryczałtu i przeszli na zasady ogólne, rozliczają zarówno podatek naliczony zawarty w dokonanych przez nich zakupach, jak i podatek należny uzyskany przy sprzedaży. Mogą oni w pełni realizować zasadę neutralności ekonomicznej podatku VAT.

Warto w tym miejscu zaznaczyć, że obydwie formy opodatkowania VAT wraz z metodami jego rozliczania (kasową/fakturową) nie mają przede wszystkim charakteru fiskalnego. Celem opodatkowania rolników jest wsparcie rozwoju gospodarstw poprzez umożliwienie wyeliminowania z kosztów podatku VAT uiszczanego przy zakupie środków produkcji. W mniejszym stopniu ma to służyć zwiększeniu dochodów budżetowych (Dziemianowicz 2006, s. 34). Jednak z punktu widzenia rolnika podstawowym problemem pozostaje pytanie: kiedy opłaca się pozostać na ryczałcie, a kiedy przejść na zasady ogólne i odwrotnie.

Odpowiedzi na powyższe pytanie oprócz autora poszukiwali m.in. Węgrzyn (2007), Filipiak (2007), Gruziel (2009), Turowska (2010), Zabielska (2011), Brodzińska (2015). Autorzy ci najczęściej dowodzili opłacalności dokonywanych przez rolników wyborów, opierając swe wyliczenia na studiach przypadku.

Pierwszy z wymienionych autorów opierając się na danych z gospodarstwa, zauważył finansowe korzyści związane z rezygnacją rolników z ryczałtowego rozliczania podatku od towarów i usług na rzecz rozliczania VAT na zasadach ogólnych. Jednocześnie słusznie podkreślił, że liczne obowiązki związane z gro- 
madzeniem dokumentacji i prowadzeniem odpowiednich rozliczeń zniechęcają rolników do korzystania z tej formy. Z punktu widzenia ostrego kryterium wyboru formy opodatkowania rozważania te miały charakter ogólny i nie wynikała z nich precyzyjna decyzja dla rolnika, które rozwiązanie wybrać.

Filipiak (2007, s. 113) analizując funkcjonujące gospodarstwo rolnicze, stwierdził, że „rolnik w systemie ryczałtowym uzyskuje większy zwrot VAT niż na zasadach ogólnych". Dla badanego podmiotu uzyskiwany od nabywcy produktów rolnych VAT zryczałtowany był ponad dwukrotnie wyższy niż przysługująca rolnikowi do zwrotu różnica pomiędzy VAT należnym a naliczonym dla opodatkowania na zasadach ogólnych. Niestety w rozważaniach tych pominięto $\mathrm{w}$ analizie porównanie dochodu uzyskiwanego z działalności rolniczej, który dla obu przypadków będzie miał odmienne wartości.

Gruziel (2009, s. 131) w wyniku przeprowadzonych badań stwierdziła, że

Podstawową kategorią wynikową pozwalającą określić skutki zastosowanych symulacji (modeli) jest kwota salda VAT ogółem. Saldo to jest sumą salda VAT z działalności operacyjnej oraz salda VAT z działalności inwestycyjnej, określanych jako różnica pomiędzy kwotą podatku należnego, a kwotą VAT naliczonego.

I dalej „Wartość salda VAT ogółem według danych rzeczywistych w gospodarstwach ryczałtowych nie ma znaczenia z uwagi na brak możliwości rozliczania podatku z urzędem skarbowym”. Trudno zgodzić się z oboma stwierdzeniami. Po pierwsze, zmiana formy opodatkowania zmienia nie tylko salda VAT, ale i wartość dochodu z gospodarstwa liczonego jako różnica przychodów i kosztów. Po drugie, to właśnie obliczane saldo VAT ogółem gospodarstwa ryczałtowego jest elementem kryterium rozstrzygającego: czy pozostawić opodatkowanie ryczałtem, czy przejść na zasady ogólne.

Turowska (2010) w swoim opracowaniu przedstawiła skutki rozrachunków VAT dla gospodarstw rolniczych, zamieszczając przykładowe obliczenia kategorii „Zysku ze sprzedaży” $i$ „Nadwyżki finansowej” dla obu form opodatkowania (tabela 1).

Tabela 1. Skutki finansowe wyboru formy opodatkowania VAT według Turowskiej

\begin{tabular}{|l|c|c|c|}
\hline \multicolumn{3}{|c|}{ Rolnik ryczałtowy } & Rolnik opodatkowany na zasadach ogólnych \\
\hline \multicolumn{3}{|c|}{ Przychody ze sprzedaży 100 ton pszenicy } \\
\hline $\begin{array}{l}\text { Wartość brutto } \\
\text { (wraz ze zryczał- } \\
\text { towanym zwrotem } \\
\text { podatku VAT) }\end{array}$ & 78000,00 & Wartość netto & 75728,16 \\
\cline { 2 - 4 } & & Podatek VAT 3\% & 2271,84 \\
\cline { 2 - 3 } & & Wartość brutto & 78000 \\
\hline
\end{tabular}


58 | Przegląd Prawno-Ekonomiczny

\begin{tabular}{|c|c|c|c|}
\hline \multicolumn{2}{|c|}{ Rolnik ryczałtowy } & \multicolumn{2}{|c|}{ Rolnik opodatkowany na zasadach ogólnych } \\
\hline \multicolumn{4}{|c|}{ Zakup środków ochrony roślin } \\
\hline Wartość netto & 22000,00 & Wartość netto & 22000 \\
\hline Podatek VAT 7\% & 1540,00 & Podatek VAT 7\% & 1540 \\
\hline Wartość brutto & 23540 & Wartość brutto & 23540 \\
\hline \multicolumn{4}{|c|}{ Zakup nawozów } \\
\hline Wartość netto & 16000 & Wartość netto & 16000 \\
\hline Podatek VAT 7\% & 1120 & Podatek VAT 7\% & 1120 \\
\hline Wartość brutto & 17120 & Wartość brutto & 17120 \\
\hline \multicolumn{4}{|c|}{ Zakup paliwa } \\
\hline Wartość netto & 10000 & Wartość netto & 10000 \\
\hline Podatek VAT 22\% & 2200 & Podatek VAT 22\% & 2200 \\
\hline Wartość brutto & 12200 & Wartość brutto & 12200 \\
\hline Zysk ze sprzedaży & 25140 & Zysk ze sprzedaży & 25140,00 \\
\hline Nadwyżka finansowa & 25140 & Nadwyżka finansowa & 27728,16 \\
\hline
\end{tabular}

\begin{tabular}{|l|c|c|}
\hline Rolnik ryczałtowy & $\begin{array}{c}\text { Wyniki } \\
\text { finansowe }\end{array}$ & $\begin{array}{c}\text { Rolnik opodatkowany na } \\
\text { zasadach ogólnych }\end{array}$ \\
\hline Oszczędności podatkowe & 2271,84 & Podatek VAT należny \\
\hline Utracone korzyści & 4860,00 & Podatek VAT naliczony \\
\hline $\begin{array}{l}\text { Straty finansowe z wyboru } \\
\text { ryczałtu }\end{array}$ & 2588,16 & $\begin{array}{c}\text { Korzyści finansowe z wyboru zasad } \\
\text { ogólnych }\end{array}$ \\
\hline
\end{tabular}

Źródło: Turowska (2010, s. 231).

Pomijając fakt, że użyte w opracowaniu pojęcie nadwyżki finansowej jest nadużyciem terminologicznym, w przedstawionej tabeli występują błędy merytoryczne. Obliczone korzyści finansowe z wyboru zasad w kwocie 2588,16 zł są błędne. Ceny skupu zbóż oraz innych roślin uprawnych podawane są zwyczajowo w kwocie netto. Przyjmując więc wartość netto przychodów 75 728,16 zł, ich wartość brutto dla rolnika opodatkowanego ryczałtem wyniesie 80 271,85 zł (w $2010 \mathrm{r}$. stawka VAT zryczałtowanego wynosiła 6\%). Wpływa to na wartość zysku ze sprzedaży (27 411,85 zł.). Dla rolnika opodatkowanego na zasadach ogólnych zysk ten jest różnicą przychodów i kosztów netto (75 728,16 zł - 22 000,00 zł 16 000,00 zł - 10 000,00 zł= 27 728,16 zł.). Różnica (korzyści ekonomiczne z wyboru zasad ogólnych) wynosi jedynie 316,31 zł i trudno się spodziewać, że rolnik zrezygnuje $\mathrm{z}$ ryczałtu.

Zabielska (2011) przedstawia dwie tabele z przykładowymi obliczeniami. W pierwszej zaprezentowała kalkulację wyników gospodarstwa rozliczającego 
się według ryczałtu. Zapłacony rolnikowi przez kupującego produkty rolne podatek VAT wyniósł 15863 zł, a hipotetyczny podatek naliczony 20046 zł. Stąd wniosek, że gospodarstwo traci na tym sposobie rozliczania VAT 4183 zł. Autorka zgłasza słuszne wątpliwości, czy kwota jest wystarczająco motywująca do przejścia na zasady ogólne.

W kolejnej tabeli został zawarty bilans tego samego gospodarstwa dokonującego rozliczenia na zasadach ogólnych przy dodatkowym wydatku inwestycyjnym na kwotę brutto 118606 zł, w tym podatek VAT jest równy 21388 zł. Łączna nadwyżka podatku naliczonego nad należnym wyniosła 33502 zł. Autorka zauważa, że w tym przypadku rozliczenie podatku od towarów i usług na zasadach ogólnych byłoby dla rolnika bardzo korzystnym rozwiązaniem. Jednak w stwierdzeniu zabrakło oceny ostatecznego kryterium korzystnego przejścia przez rolnika na VAT rozliczany na zasadach ogólnych. To przecież nie kwota zwracanego VAT naliczonego (33 502 zł) wyznacza osiągnięte przez rolnika korzyści, a kwoty netto przychodów i kosztów (powiększonych o amortyzację użytkowanej inwestycji).

Brodzińska (2015) ocenia skutki pozostania na ryczałcie dla przykładowego gospodarstwa (tabela 2). Dla danych bez uwzględnienia wydatków inwestycyjnych autorka dodaje do VAT zryczałtowanego (16 520 zł) różnicę pomiędzy VAT należnym i naliczonym po przejściu na zasady ogólne i stwierdza, że będąc na ryczałcie, rolnik zyskuje aż 18758 zł. Trudno się z tą opinią zgodzić, faktyczny zysk rolnika na ryczałcie bowiem będzie wyższy jedynie o 3394 zł. Można to obliczyć wprost z różnicy zryczałtowanego VAT i naliczonego (16 520 zł - 13126 zł) albo z różnicy zysku liczonego dla ryczałtowca (235 999 zł + 16520 zł - 106435 zł 13126 zł) i rolnika na zasadach ogólnych (235 999 zł - 106435 zł), czyli ostatecznie (132 958 zł - 129564 zł).

Tabela 2. Porównanie skutków finansowych wyboru określonej formy opodatkowania VAT według Brodzińskiej

\begin{tabular}{|c|c|c|}
\hline \multirow{2}{*}{ Wyszczególnienie } & \multicolumn{2}{|c|}{ Gospodartswo A } \\
\hline & Netto & VAT \\
\hline \multicolumn{3}{|c|}{ Sprzedaż płodów rolnych [zł]:produkcja } \\
\hline - roślinna & 117183,28 & 5859,16 \\
\hline - produkcja zwierzęca & 118815,72 & 9505,18 \\
\hline Razem & 235999,00 & 15364,34 \\
\hline \multicolumn{3}{|l|}{ Koszty produkcji [zł] } \\
\hline - materiał siewny & 10215,49 & 720,77 \\
\hline - nawóz & 33005,0 & 2640,40 \\
\hline
\end{tabular}


60 | Przegląd Prawno-Ekonomiczny

\begin{tabular}{|l|c|c|}
\hline \multirow{2}{*}{ Wyszczególnienie } & \multicolumn{2}{c|}{ Gospodartswo A } \\
\cline { 2 - 3 } \multicolumn{1}{|c|}{ Koszty produkcji [zł] } & Netto & VAT \\
\hline - środki ochrony roślin & & \\
\hline - pasze & 13000,00 & 1040,00 \\
\hline - olej napędowy & 17571,22 & 1405,70 \\
\hline - inne & 29531,84 & 6792,32 \\
\hline Razem koszty & 3111,33 & 527,11 \\
\hline VAT należny - VAT naliczony & 106434,88 & 13126,30 \\
\hline Inwestycje (średnioroczne) [zł] & & $+2238,04$ \\
\hline Rozliczenie VAT [zł] & 122750,67 & 28232,65 \\
\hline Rolnik ryczałtowy [zł] & & $-25994,61$ \\
\hline
\end{tabular}

Źródło: Brodzińska (2015, s. 60).

Dla ułatwienia wyboru formy opodatkowania rolnika VAT, oprócz opisanych powyżej szacunków w literaturze fachowej, opracowano także internetowe kalkulatory umożliwiające szybkie oszacowanie skutków odpowiedniej decyzji. Jeden $z$ nich funkcjonuje na bardzo popularnym portalu infor.pl. W tabeli 3 zamieszczono przykładowe rozliczenie według zaproponowanego algorytmu.

Przyjmując poczynione założenia, rolnik ryczałtowy przy sprzedaży na poziomie 500 tys. zł uzyskuje zryczałtowany zwrot podatku VAT w wysokości 35 tys. zł. Odejmując podatek naliczony 23 tys. zł, uzyskuje nadwyżkę ekonomiczną 12 tys. zł z tytułu opodatkowania VAT według ryczałtu. Wraz z zyskiem ze sprzedaży daje to wynik kasowy w kwocie 412 tys. zł. Dla rolnika opodatkowanego na zasadach ogólnych wynik ten wynosi 409,5 tys. zł. Wniosek: rolnik powinien dalej rozliczać VAT w formie ryczałtu.

Jednakże, podobnie jak w przypadku Turowskiej (2010), z niezrozumiałych powodów autorzy kalkulatora zmieniają kwotę sprzedaży netto z 500 tys. zł na 509,5 tys. zł. Uzasadniają to koniecznością ustalenia struktury sprzedaży, uwzględniając 5\% stawkę podatku należnego. Nie wiadomo, dlaczego ignorują wcześniej ustaloną cenę sprzedaży netto. Po skorygowaniu obliczeń zysk dla rolnika opodatkowanego na zadach ogólnych wyniesie 400 tys. zł, czyli zdecydowanie mniej niż w przypadku ryczałtu.

Dodatkowo autorzy kalkulatora zauważają, że gdyby wartość zakupów była większa o 20 tys. netto, to warto byłoby rozważyć rezygnację z ryczałtu, ponieważ rolnik uzyskałby zwrot nadwyżki podatku naliczonego nad należnym szacowanej na 2124 zł. Łącznie dałoby to rolnikowi kwotę wyniku gotówkowego: $500000 \mathrm{zł} \mathrm{-}$ $120000 \mathrm{zł}+2124 \mathrm{zł}=382124 \mathrm{zł}$. Tymczasem dla rolnika opodatkowanego 
ryczałtem wynik ten wynosiłby: 535000 zł - 147600 zł = 387400 zł. Wyższe korzyści przy wyborze ryczałtu oznaczają, że wskazania kalkulatora są błędne.

Tabela 3. Ocena skutków wyboru formy opodatkowania VAT rolnika według kalkulatora infor.pl

Przykładowe rozliczenie:

Przypuśćmy, że podsumowując przedstawione zestawienia, uzyskano następujące wyniki dla rolnika ryczałtowego (zryczałtowany zwrot podatku wynosi 7\%, zakładając również, że wszystkie zakupy były opodatkowane stawką 23\%):

\begin{tabular}{|l|c|c|c|}
\hline Suma wszystkich faktur: & Wartość netto & Podatek VAT & Wartość brutto \\
\hline Sprzedaży & $500000 \mathrm{zł}$ & $35000 \mathrm{zł}$ & $535000 \mathrm{zł}$ \\
\hline Zakupu & $100000 \mathrm{zł}$ & $23000 \mathrm{zł}$ & $123000 \mathrm{zł}$ \\
\hline
\end{tabular}

W efekcie rolnik ryczałtowy uzyskał 412000 zł, czyli od uzyskanej sprzedaży 535000 zł należy odjąć zakup na kwotę 123000 zł. Rolnik ryczałtowy nie ponosi już żadnych innych kosztów i można uznać, że 412000 zł jest tą kwotą, jaką rolnik rzeczywiście uzyskał w formie gotówki. Chcąc ustalić, ile otrzymałby rolnik, gdyby w tym samym okresie był czynnym podatnikiem VAT, należy przeprowadzić bardziej skomplikowane obliczenia. Najpierw należy ustalić strukturę sprzedaży, uwzględniając stawkę podatku 5\%, czyli sprzedaż brutto 535000 podzielić przez 1,05 co w zaokrągleniu wyniesie netto 509524 zł.

Zatem struktura sprzedaży i zakupów z przykładu powyżej będzie kształtowała się następująco:

\begin{tabular}{|l|c|c|c|}
\hline Suma wszystkich faktur: & Wartość netto & Podatek VAT & Wartość brutto \\
\hline Sprzedaży & $509524 \mathrm{zł}$ & $25476 \mathrm{zl}$ & $535000 \mathrm{zl}$ \\
\hline Zakupu & $100000 \mathrm{zł}$ & $23000 \mathrm{zl}$ & $123000 \mathrm{zł}$ \\
\hline
\end{tabular}

Rolnik - czynny podatnik VAT będzie musiał zadeklarować powyższe wartości w deklaracji VAT-7 i w efekcie zapłaci do urzędu skarbowego 2476 zł, tj. VAT należny 25476 zł minus VAT naliczony 23000 zł. Kwota podatku VAT podlegająca wpłacie do urzędu skarbowego stanowi w rozliczeniu kasowym wydatek pieniężny, który należy uwzględnić w rozliczeniu.

W efekcie rolnik czynny podatnik VAT:

+ uzyskał kasowo 535000 zł ze sprzedaży,

- wydatkował $123000 \mathrm{zł}$ na zakupy,

- wydatkował $2476 \mathrm{zł}$ na podatek VAT zapłacony do urzędu skarbowego.

Łącznie rolnik - czynny podatnik VAT uzyskał kasowo 409524 zł, tj. $535000 \mathrm{zł}$ minus $123000 \mathrm{zł}$ minus 2476 zł, czyli mniej od rolnika ryczałtowego o kwotę podatku wpłaconego do urzędu skarbowego.

Gdyby jednak zakupy zwiększyły się tylko o 20000 zł, to bardziej opłacalna byłoby dla rolnika rezygnacja ze zwolnienia, ponieważ wystąiłaby nadwyżka podatku naliczonego nad należnym (VAT od zakupu nad VAT od sprzedaży) i rolnik mógłby wystąpić o zwrot podatku w kwocie 2124 zł.

Źródło: infor.pl (2016). 
Podobny kalkulator umieszczono na portalu eGospodarka.pl w ramach Poradnika Internetu dla Twojej Firmy. Jak wykazał Kondraszuk (2016), wyniki i wnioskowanie w nim zawarte są również błędne.

\section{Próba analitycznego rozwiązania problemu rezygnacji przez rolników z ryczałtu}

Poszukując algorytmu umożliwiającego optymalny ekonomicznie wybór formy opodatkowania VAT, należy uwzględnić najważniejszą cechę owego podatku: neutralność ekonomiczną dla prowadzonej działalności gospodarczej.

Przyjęto następujące oznaczenia:

Sn - przychody ze sprzedaży netto,

Zn - wartość zakupów netto,

VS - VAT należny od sprzedaży,

VZ - VAT naliczony przy zakupach,

Zobowiązanie podatkowe (Zvat) rolnika wynosi:

$$
\mathrm{Zvat}=\mathrm{VS}-\mathrm{VZ} \text {. }
$$

Bez względu na to, czy wynika z niego konieczność zapłaty podatku (Zvat $>0$ ), czy też zwrotu z urzędu skarbowego na rachunek rolnika (Zvat $<0$ ), nie wpływa to na jego wynik ekonomiczny (WEog):

$$
\mathrm{WEog}=\mathrm{Sn}-\mathrm{Zn} \text {. }
$$

W przypadku opodatkowania ryczałtowego rolnika zasada neutralności obowiązuje kupującego produkty rolne. Rolnik ma prawo odliczyć od swojego podatku należnego zapłacony mu podatek zryczałtowany. W przypadku rolnika dodatkowe otrzymywane kwoty przy sprzedaży produktów w wysokości 7\% od cen sprzedaży netto mają zrekompensować (przynajmniej w jakiejś części) podatek VAT zapłacony przy zakupie środków produkcji, którego odliczenie rolnikowi nie przysługiwało. Niech zatem:

VSr - VAT zryczałtowany otrzymywany przy sprzedaży produktów rolnych.

VZ - jak wyżej.

Wówczas wynik ekonomiczny rolnika opodatkowanego ryczałtem (WEr) wynosi:

$$
\mathrm{WEr}=(\mathrm{Sn}+\mathrm{VSr})-(\mathrm{Zn}+\mathrm{VZ}) .
$$


Aby ocenić, czy przejście na zasady ogólne jest korzystne, należy obliczyć różnicę pomiędzy wynikiem ekonomicznym rolnika opodatkowanego na zasadach ogólnych i rolnika pozostającego przy opodatkowaniu ryczałtowym (KOv):

$$
\begin{gathered}
\mathrm{KOv}=\mathrm{WEog}-\mathrm{WEr}=(\mathrm{Sn}-\mathrm{Zn})-[(\mathrm{Sn}+\mathrm{VSr})-(\mathrm{Zn}+\mathrm{VZ})]=\mathrm{Sn}-\mathrm{Zn}-\mathrm{Sn}- \\
\mathrm{VSr}+\mathrm{Zn}+\mathrm{VZ}=\mathrm{VZ}-\mathrm{VSr} .
\end{gathered}
$$

W konsekwencji powstaje bardzo proste kryterium pozwalające na ocenę korzyści bądź strat przy wyborze formy opodatkowania. Jeżeli w wyniku oszacowań KOv jest dodatnie, to wówczas warto rozważyć wybór zasad ogólnych. Należy jednak pamiętać, że zasady ogólne to także większe obowiązki ewidencyjne łączące się z wyższymi kosztami obsługi rachunkowej gospodarstwa (Ke). Zatem jeśli rolnik opodatkowany ryczałtem rozważa przejście na zasady ogólne, kryterium opłacalności tej decyzji przybiera postać:

$$
\mathrm{KOv}=\mathrm{VZ}-\mathrm{VSr}-\mathrm{Ke}>0
$$

Jeśli rolnik opodatkowany na zasadach ogólnych rozważa wybór opodatkowania ryczałtowego, lewa strona wcześniejszej nierówności zmienia znak:

$$
\mathrm{KOv}=\mathrm{VSr}+\mathrm{Ke}-\mathrm{VZ}>0
$$

Powyższa zależność wskazuje, że pozostanie na ryczałcie opłaca się przy malejącej kapitałochłonności produkcji rolniczej oraz wysokich kosztach obsługi rachunkowej gospodarstwa. Wadą ryczałtowej formy opodatkowania jest także jej wpływ na płynność finansową. Zakupy środków produkcji poprzedzają znacznie moment uzyskania efektu (sprzedaży), a więc i zryczałtowego zwrotu.

\section{Podsumowanie i wnioski}

Problematyka opodatkowania VAT w rolnictwie pomimo dość długiej już historii dalej budzi duże zainteresowanie i wiele pytań. Szczególną troską napawa fakt niejednoznacznej interpretacji skutków ekonomicznych funkcjonowania VAT w rolnictwie. Ze względu na rosnące w gospodarstwach obroty po stronie sprzedaży i zakupów bardzo ważna dla rolnika staje się decyzja o rezygnacji z ryczałtu i przejście na zasady ogólne. W pracy przedstawiono analityczne kryterium pozwalające na oszacowanie skutków takiej decyzji. Prezentowany etap 
prac nad istotą podatku VAT upoważnia i wręcz obliguje do podjęcia dalszych badań zarówno nad prawnymi (teoretycznymi), jak i ekonomiczno-finansowymi (praktycznymi) problemami uwzględniania wpływu podatku VAT na prowadzenie działalności rolniczej przez rolników. Dla rolników ważny jest sposób prowadzenia ewidencji VAT, poczynając od rejestracji pojedynczego zdarzenia gospodarczego do sporządzenia właściwej deklaracji dla urzędu skarbowego. Właściwa ewidencja podatkowa może stać się początkiem upowszechniania prostej księgowości w gospodarstwach.

\section{Bibliografia}

\section{Akty prawne}

Ustawa z dnia 8 stycznia 1993 r. o podatku od towarów i usług oraz o podatku akcyzowym, Dz.U. 1993, nr 11, poz. 50 z poźn. zm.

Ustawa z dnia 20 lipca 2000 r. o zmianie ustawy o podatku od towarów i usług o o podatku akcyzowym i opłacie skarbowej, Dz.U. 2000, nr 68, poz. 805.

Ustawa z dnia 11 marca 2004 r. o podatku od towarów i usług, Dz.U. 2004, nr 54, poz. 535 z późn. zm.

\section{Literatura}

Brodzińska, K. (2015). Podatek VAT w rolnictwie a proces modernizacji gospodarstw rolnych - studium przypadku. Roczniki Naukowe Stowarzyszenia Ekonomistów Rolnictwa i Agrobiznesu, 17(3), 56-61.

Dziemianowicz, R. (2006). Podatek od wartości dodanej a rynek rolny. Roczniki Naukowe Stowarzyszenia Ekonomistów Rolnictwa i Agrobiznesu, 8(2), 30-34.

Filipiak, T. (2007). Podatek VAT w gospodarstwach rolnych. Roczniki Naukowe Stowarzyszenia Ekonomistów Rolnictwa i Agrobiznesu, 9(1), 109-114.

Gruziel, K. (2009). Skutki zmian w rozliczaniu podatku VAT w gospodarstwach indywidualnych. Roczniki Naukowe Stowarzyszenia Ekonomistów Rolnictwa i Agrobiznesu, 11(1), 130-135.

Kalkulator VAT w rolnictwie: ryczalt czy VAT? Pobrano z: www.podatki.egospodarka.pl/ kalkulator/vat-w-rolnictwie-ryczalt-czy-vat (12.03.2020).

Kondraszuk, T. (2016). Wybrane problemy rozliczania VAT w rolnictwie. Roczniki Naukowe Stowarzyszenia Ekonomistów Rolnictwa i Agrobiznesu, 18(2), 155-160. Kondraszuk, T. (2017a). Ryczałt czy zasady ogólne rozliczania VAT w rolnictwie? Zeszyty Naukowe Wyższej Szkoły Ekonomiczno-Społecznej w Ostrołęce, 3(26), 182-191. 
Kondraszuk, T. (2017b). Metoda kasowa rozliczania VAT w rolnictwie. Roczniki Naukowe Stowarzyszenia Ekonomistów Rolnictwa i Agrobiznesu, 19(5), 113-118. doi: $10.5604 / 01.3001 .0010 .6216$

Kondraszuk, T., Jaworski, J. (2017). W poszukiwaniu kryterium wyboru formy opodatkowania VAT w rolnictwie. Finanse, Rynki Finansowe, Ubezpieczenia, 1, 47-58. doi: 10.18276/frfu.2017.1.85-04

Kondraszuk, T. (2018). Wybrane problemy stosowania metody kasowej na potrzeby rozliczania podatków w rolnictwie. Prace Naukowe Uniwersytetu Ekonomicznego we Wrocławiu, 522, 236-248. doi: 10.15611/pn.2018.522.17

Kondraszuk, T., Jaworski, J. (2018a). Wybór formy opodatkowania VAT a koszty i korzyści rolnika. Prace Naukowe Uniwersytetu Ekonomicznego we Wrocławiu, 503, 226-235. doi: 10.15611/pn.2018.503.20

Kondraszuk, T., Jaworski, J. (2018b). The dilemma of choosing the form of VAT taxation in agriculture in Poland. W: A. Auzina (Ed.), Bioeconomy. Finance and taxes. Home economics. New dimensions in the development of society. Proceedings of the International Scientific Conference, 9-11 May 2018, Jelgava, Latvia (s. 124130). Jelgava: Latvia University of Life Sciences and Technologies. doi: 10.22616/ ESRD.2018.127

Nachtman, G., Cholewa, I. ( 2016). VAT w funkcjonowaniu gospodarstw rolnych w latach 2010-2013. Zagadnienia Ekonomiki Rolnej, 2(347), 143-161.

Namysłowski, R., Pokrop, D. (red.). (2012). Dyrektywa VAT. Polska perspektywa. Warszawa: Wolters Kluwer Polska.

Pasieczna, E. (2014). Czy rolnikowi opłaca się być czynnym podatnikiem VAT? Pobrano z http://ksiegowosc.infor.pl/podatki/podatki-na-wsi/142109,Czy-rolnikowi-oplaca-sie-byc-czynnym-podatnikiem-VAT.html (12.03.2020).

Szelągowska, A. (2014). Zmiany w opodatkowaniu polskiego rolnictwa po akcesji Polski do Unii Europejskiej. Roczniki Naukowe Ekonomii Rolnictwa i Rozwoju Obszarów Wiejskich, 101(2), 123-125.

Szelągowska, A., Goraj, L. (2000). Podatek od towarów i usług (VAT) w rolnictwie. Warszawa: Wielkoposkie Stowarzyszenie Sołtysów.

Turowska, W. (2010). Ewidencja, rozliczenie i skutki rozrachunków przedsiębiorstw rolniczych z tytułu podatku VAT. Zeszyty Naukowe SGGW w Warszawie. Ekonomika i Organizacja Gospodarki Żywnościowej, 82, 229-237.

Węgrzyn, A. (2007). Metodyka ewidencji i rozliczania VAT w rolnictwie. Roczniki Naukowe Stowarzyszenia Ekonomistów Rolnictwa i Agrobiznesu, 9(1), 532-536.

Zabielska, D. (2011). Uwarunkowania zasad funkcjonowania podatku VAT w gospodarstwach rolnych. Zeszyty Naukowe SGGWw Warszawie. Ekonomika i Organizacja Gospodarki Żywnościowej, 89, 61-73. 


\section{Streszczenie}

Głównym celem artykułu jest przedstawienie najważniejszych dylematów prawnoekonomicznych związanych z funkcjonowaniem VAT w rolnictwie. Kwestia kluczowa dotyczy oceny skutków ekonomicznych i finansowych podatku od wartości dodanej w gospodarstwie rolnym. Rolnik rozlicza VAT w systemie ryczałtowym lub według zasad ogólnych. Przeanalizowano strony internetowe zawierające „kalkulatory” wspomagające obliczenia skutków rezygnacji rolników z ryczałtu i przejścia na zasady ogólne oraz wybrane publikacje z lat 2000-2016 podejmujące problematykę VAT w rolnictwie. Okazało się, że pomimo kilkunastoletniego obowiązywania tego podatku w rolnictwie jego zasady funkcjonowania są niewłaściwie interpretowane i wiele wątpliwości wzbudzają prezentowane przez poszczególnych autorów skutki ekonomiczne przejścia na zasady ogólne.

SŁowA KLUCzowe: VAT, rolnictwo, rolnik ryczałtowy, zarządzanie.

\section{Summary}

The main objective of this paper is to present legal and economic problems associated with the functioning of VAT in farming. The key issue concerns the assessment of economic and financial effects of value added tax on an agricultural holding. A farmer accounts for VAT on a flat-rate basis or on a general basis. Webpages offering online "calculators" which are supposed to help farmers asses the results of switching from the flat-rate method to a general basis method, as well as selected research on the topic of VAT in agriculture published between 2000 and 2016 have been analysed. As it turned out, in spite of the fact that VAT in farming has been functioning for several years, the it has been wrongly interpreted and the economic effects of the resignation of farmers from the flat-rate status have been incorrectly presented.

KEYwORDs: value added tax (VAT), agriculture, a flat-rate farmer, management.

\section{Nota o autorze}

Tomasz Kondraszuk - dr inż., adiunkt, Katedra Ekonomiki i Organizacji Przedsiębiorstw, Szkoła Główna Gospodarstwa Wiejskiego w Warszawie; główne obszary działalności naukowej: ekonomika i organizacja gospodarstw rolniczych, rachunkowość, systemy wspomagające podejmowanie decyzji, controlling; e-mail: tomasz_kondraszuk@sggw.pl; ORCID: 0000-0003-0359-3123. 